\title{
Edukasi Vaksin dan Prokes 5M bagi Remaja-Pemuda Sebagai Gerakan Spiritualitas Pro Hidup Hadapi Pandemi COVID-19 di Jemaat Bethania dan Menara Kasih, Klasis GPM Kota Ambon
}

\author{
Adam Lakarang, Lidya Parera, Bernhard Marantika, Charles Maloky, Febry Walaia, \\ Marco Wedilen, Iluy Noija, Carollus de Queljoe, \& Eklefina Pattinama*
}

Universitas Kristen Indonesia Maluku, Indonesia

\begin{abstract}
Pengabdian kepada masyarakat ini ditujukan kepada pemuda-remaja untuk mengikuti vaksin dan mematuhi protokol kesehatan 5M, serta melakukan gerakkan spiritualitas pro hidup dengan aksi bersih lingkungan, mengajak teman sebaya disiplin menggunakan protokol kesehatan 5M. Berbagai cara digunakan untuk memutuskan mata rantai penyebaran Virus Corona. Cara ini dalam masa Pandemi COVID-19 digunakan untuk mewujudkan gerakan spiritualitas pro hidup kepada pemuda dan remaja, juga dengan cara, memberi penjelasan tentang Vaksin, mematuhi protokol kesehatan 5M dan disiplin melakukan gerakan spiritualitas pro hidup dengan merawat diri dan juga merawat teman/orang lain. Ada pun metode pembinaan dimulai dari rencana, pelaksanaan, membangun kerja sama dengan mitra dan pelaksanaan kegiatan. Model gerakan spiritualitas pro hidup yang digunakan adalah mendampingi dan mendorong pemuda remaja mengambil keputusan untuk vaksin dan tetap mematuhi protokkol kesehatan agar pemuda remaja dapat menggerakkan teman sebaya untuk displin protokol kesehatan 5M dan mengikuti vaksin dalam merawat hidup di masa Pandemik COVID-19. Gerakan spiritualitas pro hidup bagi pemuda dan remaja sangat penting bagi masa depan mereka untuk menumbuhkan iman mereka sebagai karya Allah yang menyelamatkan pemuda dan remaja gereja di masa pandemik.
\end{abstract}

Keywords: COVID-19; Pentingnya Vaksin; Protokol kesehatan 5M; Spiritualitas Pro-Hidup.

\section{Pendahuluan}

Jemaat GPM Menara Kasih secara administrasi Pemerintahan berada di wilayah Kota Ambon, Kecamatan Nusaniwe, Kelurahan Mangga Dua, dengan luas wilayah $\pm 183.188 \mathrm{~m}^{2}$. Secara geografisi-adminsitratif pelayanan GPM, Jemaat GPM Menara Kasih berbatasan dengan beberapa Jemaat GPM lain yaitu sebagai berikut: Sebelah Utara berbatasan dengan Jemaat GPM Kategorial Sinar Kasih dan Jemaat GPM Silo serta gereja Advent Hari Ketujuh, Sebelah Selatan berbatasan dengan Jemaat GPM Ora et Labora, Sebelah Barat berbatasan dengan Jemaat GPM Rehoboth, Sebelah Timur berbatasan dengan Jemaat GPM Silo dan gereja GBI, Secara khusus di sebelah Utara Jemaat GPM Menara Kasih bersinggungan pula dengan warga Islam di daerah Perigi Lima, Waehaong, Soabali, Air Mata Cina dan Ponegoro. Sebagai Jemaat di wilayah pusat Kota Ambon dan dalam persinggungan dengan Jemaat GPM non GPM lain termasuk warga Islam maka diperlukan pengembangan berbagai potensi relasional dan kerja sama (Majelis Jemaat, 2021). Berbagai persoalan dan masalah termasuk pandemi COVID-19 berdampak dan mempengaruhi tatanan kehidupan sosial, pendidikan, dan Perekonomian bagi jemaat ini.

\footnotetext{
* Corresponding author:

E-mail address: eklefinap@gmail.com
} 
Corona merupakan jenis virus yang dapat menyebabkan penyakit pada hewan dan manusia. Pada manusia, coronavirus dapat menginfeksi saluran nafas mulai dari batuk pilek hingga dapat mengakibatkan Middle East Respiratory Syndrome (MERS) dan Severe Acute Respiratory Syndrome (SARS). Penyebaran COVID-19 yang telah meluas termasuk di Indonesia merupakan ancaman yang serius (Latifah, 2020). Virus ini adalah virus yang dapat saja mengakibatkan seseorang mengalamai kematian mengapa karena virus menyerang saluran pernapasan pada manusia. Wabah Corona Virus Disease tahun 2019 (COVID-19) tidak hanya dirasakan pada sektor kesehatan, tetapi juga merambah ke seluruh sendi kehidupan, termasuk pendidikan (Wakhudin, 2020). Virus ini tidak hanya menyerang orang muda dan juga remaja tetapi siapa saja bisa terkena virus yang membahayakan ini.

Pandemic COVID-19 menyerang banyak aspek selain pendidikan yang mengakibatkan pendidikan berjalan secara daring (Masela, 2020) tetapi juga ekonomi dan juga kesehatan, termasuk kesehatan mental. Dampak ini sangat dialami dan itu membuat setiap orang menjadi takut dan gelisah. Masyarakat dihimbau untuk mengurangi aktivitas luar rumah seperti Kantor, Sekolah, tempat olahraga dan semua tempat yang berpotensi mengumpulkan banyak orang dengan maksud untuk memperlambat penyebaran virus corona (Pratama, 2020). Dengan cara inilah dapat memutuskan mata ranntai penyebaran virus yang membahayakan ini. Jemaat GPM Bethania dan Menara Kasih juga mengalami dampak dari pandemic COVID-19. Baik berdampak bagi kesehatan maupun pendidikan anak-anak. Kuliah Kerja Nyata (KKN) Universitas Kristen Indonesia Maluku (UKIM) pada masa pandemi ini diprogramkan untuk dilaksanakan pada kawasan tempat tinggal mahasiswa sehingga mempermudah pelaksanaan program kerja yang direncanakan serta mempermudah koordinasi dengan jemaat/masyarakat terkait. Mahasiswa juga didampingi secara online untuk bagaimana memprogramkan kegiatan-kegiatan serta menulis kronologis hasilnya berupa artikel hasil pengabdian masyarakat (Touwely, et.al., 2019).

Maluku merupakan salah satu Provinsi yang terdampak Pandemi COVID-19. Data angka kematian di kota Ambon pada tanggal 16 Agustus 2021 berjumlah 155 Orang (Pemerintah Kota Ambon, 2021). Kasus ini menunjukkan bahwa tingkat kematian karena virus corona di kota Ambon terus ada. Corona virus semakin meningkat di Kota Ambon termasuk di Kelurahan Mangga Dua, kecamatan Nusaniwe. Ada orang tanpa Gejala (OTG), yang tinggal dalam satu rumah dengan orang tidak terkonfirmasi Reaktif atau Positif (Negatif). OTG juga menjadi sebuah masalah bagi Kesehatan orang yang negative karena dapat saja ia tertular dari mereka yang Positif jika mereka tidak mematuhi Protokol Kesehatan (5M) dan melakukannya dengan ketat. Vaksin merupakan produk biologi yang berisi antigen yang bila diberikan kepada seseorang akan menimbulkan kekebalan spesifik secara aktif terhadap penyakit tertentu. Vaksin COVID-19 bukanlah obat. Vaksin mendorong pembentukan kekebalan spesifik pada penyakit COVID-19 agar terhindar dan tertular ataupun kemungkinan sakit berat (Kementerian Kesehatan RI, 2020). Saat ini vaksin COVID-19 yang dilakukan diperuntukan bagi usia 18-60 tahun dan 12-17 tahun. Pentingnya pemerintah melakukan program vaksinasi kepada masyarakat di tengah kondisi pandemic COVID-19, supaya dengan vaksinasi akan membuat tubuh seseorang mengenali bakteri/virus (COVID-19) akan menjadi lebih kebal.

Di jemaat GPM Menara kasih dan Bethania, khususnya di kalangan remaja yang belum vaksin sebanyak 81 orang, sedangkan rata-rata anak remaja jumlah 85 orang, dan terdapat 93 pemuda yang belum divaksin dari jumlah pemuda 112 orang. Pada jemaat Bethania ada 123 pemuda dan anak remaja 94 orang yang belum vaksin. Yang membuat sehingga remaja dan pemuda di dua jemaat ini belum vaksin dikarenakan, merasa takut untuk memberikan diri mereka divaksin. Padahal, efek perlindungan vaksin COVID-19 terhadap tubuh aman dan justru meningkatkan kekebalan tubuh seseorang terhadap penularan COVID-19. Perlindungan vaksin yang diberikan bagi tubuh nantinya akan bekerja, tapi perlu juga untuk remaja dan pemuda tetap mematuhi dan melakukan protokol kesehatan 5M: mencuci tangan dengan sabun, memakai masker dengan benar, menjaga jarak 1-2 meter, mengurangi mobilitas, menjauhi kerumunan dengan ketat.

Pemuda adalah individu yang bila dilihat secara fisik sedang mengalami perkembangan dan secara psikis sedang mengalami perkembangan emosional, sehingga pemuda merupakan sumber daya manusia pembangunan baik saat ini maupun masa datang (Kabupaten Buleleng, 2021). Dari penjelasan ini dapat dilihat bahwa pemuda adalah masa depan keluarga, gereja tetapi juga bangsa yang harus dipersiapkan untuk menjadi lebih baik agar dapat menciptakan daya pembangunan di masa yang akan datang. Remaja adalah sebagai salah satu proses pendewasaan yang merupakan awal dalam mengenal dan menegerti serta menyelami proses kedewasaan. Kata remaja berasal dari bahasa Latin yaitu Adolesence, yang artinya tumbuh atau tumbuh untuk mencapai kematangan (Nurmalita, 2016). 
Memang tidak dapat di pungkiri, pemuda dan remaja dengan usianya yang masih begitu muda sangat berdampak pada psikologi mereka ketika berhadapan masalah pandemic seperti COVID-19 ini. Kebanyakan remaja pada masa Pandemi COVID-19 terlihat murung, sedih dan kecewa ketika semua proses aktifitas dirumahkan (Azmi, 2021). Akibatnya remaja hanya menghabiskan waktu menggunakan media sosial untuk melawan rasa tadi, sehingga tidak heran kalau remaja lebih banyak menyerap berita-berita bohong (hoax) lewat berbagai media sosial. Dengan demikian, langkah edukasi tidak boleh berhenti diberikan kepada remaja, agar remaja dengan sungguh-sungguh membawa diri untuk mengikuti vaksinasi, dan tidak sebagai bentuk tindakan ikut-ikutan, melainkan karena kepentingan bersama untuk tetap pro terhadap kehidupan. Begitu pula dengan pemuda, mesti mengikuti vaksin sebagai bentuk panggilan iman yang pro hidup.

Pentingnya penguatan spiritualitas bagi pemuda sebab, pemuda adalah sumber daya manusia yang sangat penting bagi pembangunan jemaat dan masyarakat, bangsa dan negara secara bersamaan dan terpadu (Lewier, 2003). Pada pemuda sebagai individu yang memiliki semangat dan kreativitas tinggi yang disalurkan melalui berbagai bidang seperti hobi dan pekerjaan (Hurlock, 2013). Pemuda pada priode usia 20an (pemuda) sebagai "periode dalam kehidupan dimana pandangan iman mereka rentan untuk berubah (Dariyo, 2003). Bila pemuda memiliki spiritualitas yang kuat, maka kualitas hidup yang mencakup tanggung jawab, kesejahteraan dan kesehatan spiritual mesti nampak dalam kehidupan iman pemuda gereja.

"Spiritualitas" merupakan suatu kata yang bersifat universal karena bisa digunakan oleh semua agama, karena spiritualitas itu sendiri merupakan "saripati religius" yang ada di balik ajaran atau aturan-aturan formal agama. Spiritualitas justru sangat dekat dan menghidupi kehidupannya kini dan spiritualitas bukan hidup rohani yang terpisah dari dunia, seperti yang dikatakan Richard O'Brien: "spritualitas berkaitan erat dengan pengalaman bersama Allah dan trasformasi kesadaran manusia dan kehidupan sebagai pengalaman (Haryono, 2010). Dalam konteks hidup pemuda beriman, spiritualitas mengandung pengertian tentang apa yang dapat mendorong, memotivasi, menghidupkan, dan menumbuhkan diri pemuda. Oleh karena itu, antara apa yang diimani dan apa yang dilakukan berjalan seiring dalam relasinya dengan sesama dan dunia secara konkrit (McGrath, 2007). Perrin menyatakan bahwa spiritualitas Kristen menujukan bahwa Allah yang diyakini didalam Kristus dan dalam kehidupan seorang Kristen berinteraksi merujukan pada kehidupan Kristus dan spirit, Roh Kudus memerintah dalam hidup (Anamofa, 2013). Oleh karena itu, antara apa yang diimani dan apa yang dilakukan berjalan seiring dalam relasinya dengan sesama dan dunia secara konkret semua ini membutuhkan displin rohani (Perrin, 2007).

Hadapi Pandemi COVID-19, pemuda gereja membutuhkan displin rohani. Disiplin secara sederhana dapat diartikan sebagai latihan yang diharapkan dapat menghasilkan sifat atau karakter bahwa disiplin rohani itu sebagai sebuah latihan pikiran dan emosi untuk mendekatkan diri kepada Allah (Mutak, 2016). Disiplin rohani adalah sarana untuk mengembangkan kerohanian seseorang yang telah mengalami perubahan oleh Kristus pada saat ia diselamatkan, yang lewat anugerah-Nya membebaskan pemuda kristen mengalami pembaharuan seara holistik, yang diwujud nyatakan lewat perubahan dalam pikiran, perasaan, dan karakter yang secara bertahap menjadi nyata di dalam perilaku pemuda disaat pemuda mengalami perjumpaan dengan Kristus, menerima Dia sebagai Tuhan (Hughes, 2001).

Ada banyak jenis dan praktek disiplin rohani yang dikembangkan menurut J. Wilhoit umpamanya, menyakini bahwa Tuhan Yesus memberikan tiga disiplin rohani yang dapat menolong pertumbuhan percaya yaitu membahas empat disiplin rohani yang terkait dengan ibadah pribadi, yaitu disiplin bermeditasi, disiplin berdoa, disiplin berpuasa dan disiplin keheningan (Wilhoit, 2008). Hadapi pandemic COVID-19, pemuda perlu melakukan displin diri dengan bermeditasi, Richard Foster tentang meditasi Kristen sebagai berikut: meditasi Kristen membawa pemuda kepada keutuhan batin memberi diri dengan leluasa kepada Tuhan dan mendengar Allah berbicara dan terus menerus berbicara kepadanya. Doa sebagai displin rohani sebagai permohonan pada Allah, membangun relasi dengan Allah tetapi juga dengan sesama manusia (Foster, 2005). Disiplin puasa akan menolong bukan hanya sekedar belajar untuk menguasai atau mengotrol nafsu makan, tetapi disiplin puasa menolong untuk belajar menahan diri dari hal-hal yang bersifat keinginan diri manusia. Serta bagaimana dapat menahan dan menolak semua keinginan itu dan berfokus pada Tuhan Allah. Disiplin Keheningan secara sederhana dapat diartikan sebagai menahan diri dari berbicara untuk sementara waktu guna mencapai tujuan rohani (Darmaputera, 2010).

Keempat displin rohani di atas sebagai penguatan spirtualitas pemuda gereja mestinya menjadi spiritualitas sehari-hari (Adiprasetya, 2006) pemuda hadapi pademi COVID-19, agar pemuda gereja memiliki tubuh sehat. Jika spiritualitas 
kesehatan pemuda kuat baik secara jasmani maupun rohani, pemuda dapat memiliki peran sentral dalam perubahan bangsa. Pentinglah bagi pemuda gereja memahami penguatan spiritualitasnya menuju hidup sehat. Kurangnya pemahaman pemuda dan remaja Jemaat GPM Menara Kasih dan Bethania tentang pentingnya Vaksin dan menjaga kekebalan tubuh pribadi dan kelompok, Kurangnya kesadaran warga jemaat (Pemuda dan Remaja) terhadap protokol kesehatan (Penerapan 5M), Kurangnya Kesadaran Pemuda-Remaja tentang pentingnya penguatan spiritualitas serta gerkan spiritua;itas yang mendorong sesama pemuda (Teman Sebaya) mengikuti vaksin, Belum tergeraknya pemudaremaja memberi diri untuk vaksin, Belum terlibatnya pemuda remaja dalam penyemprotan Disenvektan di lingkungan mencegah penularan COVID.

\section{Permasalahan Prioritas Mitra}

Berdasarkan pengamatan terhadap proses vaksinasi dan kepatuhan menerapkan protokol kesehatan di masa pandemi COVID-19 oleh pemuda dan remaja, sebagaimana diungkapkan dalam hasil-hasil penelitian di atas, maka dapat dirumuskan beberapa poin permasalahan yang dapat didiskusikan bersama dengan mitra demi mencari solusi bersama atas permasalahan yang terjadi. Masalah yang ditemukan, yakni:

a) Kurangnya pemahaman pemuda dan remaja Jemaat GPM Menara Kasih dan Bethania tentang pentingnya Vaksin dan menjaga kekebalan tubuh pribadi dan kelompok.

b) Kurangnya kesadaran warga jemaat (Pemuda dan Remaja) terhadap protokol kesehatan (Penerapan 5M).

c) Kurangnya Kesadaran Pemuda-Remaja tentang pentingnya penguatan spiritualitas serta gerkan spiritualitas yang mendorong sesama pemuda (Teman Sebaya) mengikuti vaksin.

d) Belum tergeraknya pemuda-remaja memberi diri untuk divaksin.

e) Belum terlibatnya pemuda remaja dalam penyemprotan disinfektan di lingkungan demi mencegah penularan COVID-19.

\section{Solusi Permasalahan}

Dari lima persoalan prioritas mitra yang dirumuskan di atas, maka solusi yang disepakati adalah:

a) Sosialisasi terkait vaksin dan penerapan Prokes $5 \mathrm{M}$ melalui webinar pada pemuda dan remaja di kedua jemaat. Webinar ini dilakukan agar adanya peningkatan pemahaman pemuda-remaja tentang vaksin untuk meningkatkan imun tubuh hadapi ancaman COVID-19 dan juga pentingnya penerapan Prokes 5M. Dari 85\% pemuda dan remaja yang mengikuti proses webinar, diharapkan dapat memahami tentang pentingnya vaksin dan mematuhi Prokes 5M bagi pemuda dan remaja demi menjaga dan merawat kehidupan. Harapannya, pemuda remaja bisa terus menerapkan Prokes 5M dan mengikuti vaksin demi meningkatkan herd immunity.

b) Kegiatan yang dilakukan tim bagi mitra hanya berjalan sekali untuk setiap kegiatan. Mereka akan teredukasi untuk terus memberikan pencerahan dan mengajak teman-teman yang lain dalam mematuhi protokol kesehatan 5M dan mengikuti vaksinasi guna bersama-sama meningkatkan spiritualitas pemuda remaja yang pro hidup.

c) Melalui kegiatan yang dilakukan, pemuda remaja juga akan tergerak hati dan peduli terhadap kondisi sekarang dan mengambil bagian bersama dengan warga jemaat untuk menjaga lingkungan tetap steril dan bersih dalam mencegah penyebaran COVID-19.

\section{Metode Pelaksanaan}

Tahapan pelaksanaan dimulai dari kampus kemudian dilakukan Pertemuan Tim untuk pembagian tugas, melakukan Koordinasi kelompok dan instruktur: Pedekatan dengan Mitra untuk penetapan waktu pelaksanan dan penerapan kegiatan. Kordinator kelompok: Mempersiapkan administrasi: Persiapan Daftar hadir peserta, pelaksanaan KKN PPM di Jemaat GPM Bethania dan Menara Kasih. Kordinator dan instruktur merancang kegiatan yang akan dilaksanan antara lain: Sosialisasi tentang Vaksin melindungi diri Pemuda dan Remaja dari ancaman COVID-19, Sosialisasi tentang pentingnya ketaatan pada protokol kesehatan (5M), Sosialisasi tentang Vaksin sebagai gerakan spiritualitas pro hidup (Gerakan penyelamatan) bagi pemuda dan remaja di jemaat, Kegiatan pendataaan pemuda dan remaja untuk 
vaksin serta mendampingi di saat vaksin, Kegiatan penyemprotan dan menggunakan 5M di masa pandemik COVID19. Pertemuan dengan Mitra Rapat Tim dan Mitra untuk memutuskan: Jadwal pelaksanaan kegiatan Sosialisasi, Menginformasikan materi yang akan disampaikan pada kegiatan Sosialisasi, Mengatur Mekanisme Pelaksanaan kegiatan, Membagi tugas dengan mitra untuk kelancaran kegiatan sosialisasi melalui webinar.

\section{Hasil dan Luaran yang Dicapai}

Berdasarkan kesepakatan Tim dan mitra, maka peserta kegiatan adalah pemuda dan remaja. Berdasarkan hal itu, maka diadakan pertemuan antara tim dengan mitra untuk merencanakan berjalannya kegiatan yang dirancang. Dari rencana kerja pelaksanaan yang telah dibuat dan disepakati dalam rapat tim bersama mitra, maka kegiatan terbagi dalam beberapa tahapan pelaksanaan sebagai berikut:

\section{1) Pelaksanaan Sosialisai Tentang Vaksinasi dan Prokes 5M}

Webinar adalah istilah umum dalam dunia kajian yang merujuk kepada seminar yang dilakukan secara daring, menggunakan situs, link, atau aplikasi tertentu berbasis internet. Cara ini memungkinkan pembicara atau pemateri membagikan informasi pada mereka yang jarak jauh lewat internet maupun media elektronik lainya. Sosialisasi yang kami lakukan bertujuan untuk mengadvokasikan masyarakat dalam jemaat terlebihnya kepada pemuda remaja yang ada di dalam jemaat masing-masing (Menara Kasih dan Bethania). Ada banyak di antara mereka yang terobsesi terhadap isu-isu berkembang tentang vaksinasi COVID-19, dan ada di antara mereka yang tidak mau sama sekali untuk di vaksin karena dianggap akan membawakan mereka pada kematian. Melihat hal ini, maka tim bersepakat untuk melakukan webinar ini agar dapat memberikan pemahaman/edukasi tentang pentingnya vaksinasi bagi diri pemuda remaja. Pada tahapan ini, tim melakukan webinar atau sosialisasi tentang manfaat vaksin bagi masyarakat terlebih khususnya kepada pemuda yang ada dalam jemaat GPM Menara Kasih dan jemaat GPM Bethania. Sosialisasi yang dilakukan oleh tim, terlebih dahulu kami melakukan pertemuan dengan Ketua Majelis Jemaat di jemaat masing-masing untuk melaksanakan program ini serta melakukan pendekatan dengan pemuda remaja. Kegiatan webinar ini melibatkan semua unsur yang ada dalam jemaat, terlebih khususnya kepada pemuda remaja. Pada tanggal 16 Juli 2021 tim melaksanakan program Webinar ini, dan prosesnya pun berjalan dengan baik. Mitra begitu antusias dan aktif dalam mengikuti webinar ini sampai selesai.

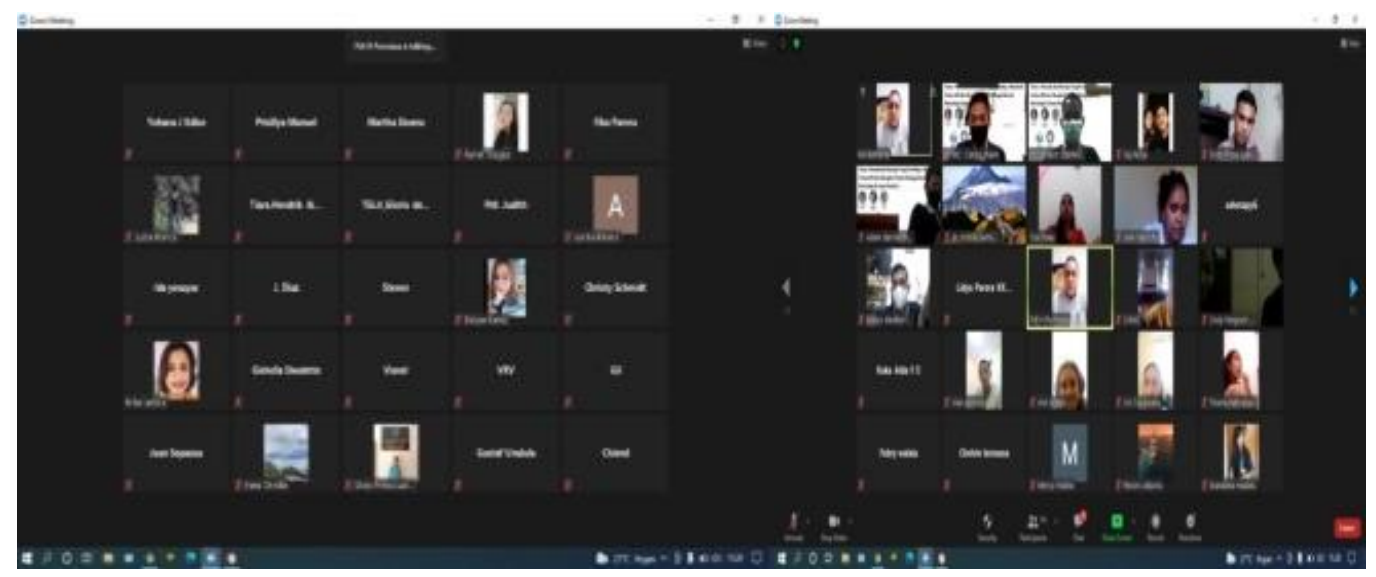

Gambar 1. Kegiatan Webinar Tentang Pentingnya Vaksin dan Penerapan Prokes 5M

\section{2) Penyemprotan Disinfektan di Ranting Epta dan Victorius Cabang Bethania}

Pada tahapan pelaksanaan kegiatan ini, mitra diminta oleh tim untuk melakukan penyemprotan disinfektan di ranting masing-masing. Penyemprotan disinfektan ini dilakukan dengan tujuan untuk mengantisipasi penyebaran Virus COVID-19. Penyemprotan disinfektan dilakukan pada semua rumah warga jemaat yang ada di Ranting Epta dan Ranting Victorius dan juga di pos-pos tempat tongkrongan anak muda di kedua Ranting tersebut. Pelaksanaan kegiatan 
ini berlangsung dua kali pada hari Minggu, 8 Agustus 2021 di Ranting Victorius dari jam 15.00-17.00 WIT dan pada hari Rabu, 11 Agustus 2021 di Ranting Epta dari jam 13.00-15.00 WIT.

Pelaksanaan program ini dimulai dari pendekatan tim dengan pengurus Ranting Epta dan Ranting Victorius. Selanjutnya tim menyiapkan bahan-bahan untuk pembuatan cairan disinfektan yaitu Wipol, Rinso dan Bayclin. Tim juga menyiapkan pelindung diri seperti masker, sarung tangan karet dan nurse cap. Untuk alat penyemprotan dan APD disiapkan oleh mitra, yaitu pengurus Ranting Epta dan Ranting Victorius karena mitra sudah mempunyai alat penyemprotan dan APD sendiri. Memulai kegiatan penyemprotan tim membuka dengan doa dan selanjutnya tim dan mitra mempersiapkan cairan dan APD untuk dipakai oleh penyemprot. Seletah semuanya siap, mitra dan tim berjalan bersama ke rumah-rumah dan pos-pos tongkrongan untuk melakukan penyemprotan dan pada pos-pos disemprot sebanyak dua kali. Setelah selesai dengan penyemprotan, tim dan mitra kembali ke titik kumpul awal untuk foto bersama sebagai dokumentasi dan di tutup dengan doa. Sebelum berpisah, tim membantu mitra untuk membersihkan alat-alat dan APD yang sudah digunakan sebelumnya.

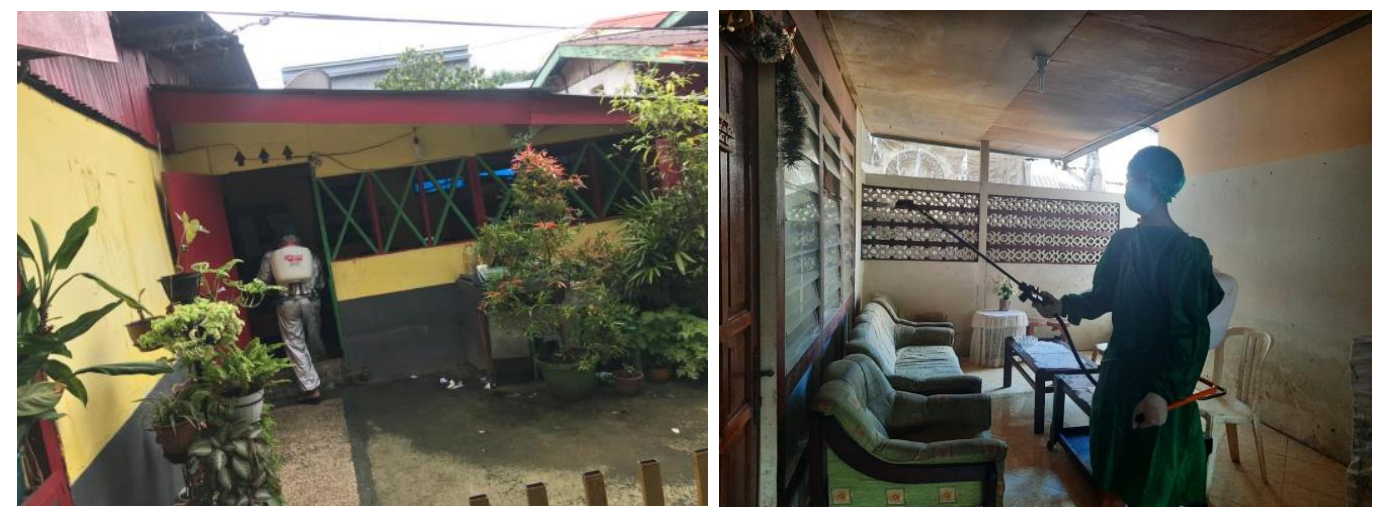

Gambar 2. Proses Penyemprotan Disinfektan di Rumah Jemaat

\section{3) Pendataan Vaksinasi di Jemaat GPM Menara Kasih}

Pendataan vaksinasi di jemaat GPM Menara Kasih di lakukan pada Tanggal 3-5 Agustus 2021. Kegiatan ini bertujuan untuk mendata mitra yang belum dan sudah di vaksin. Bentuk kegiatannya adalah tim melakukan pendataan pada keempat Sektor di Jemaat Menara Kasih, yakni Sektor Eden, Sion, Getsemani dan Karmel.
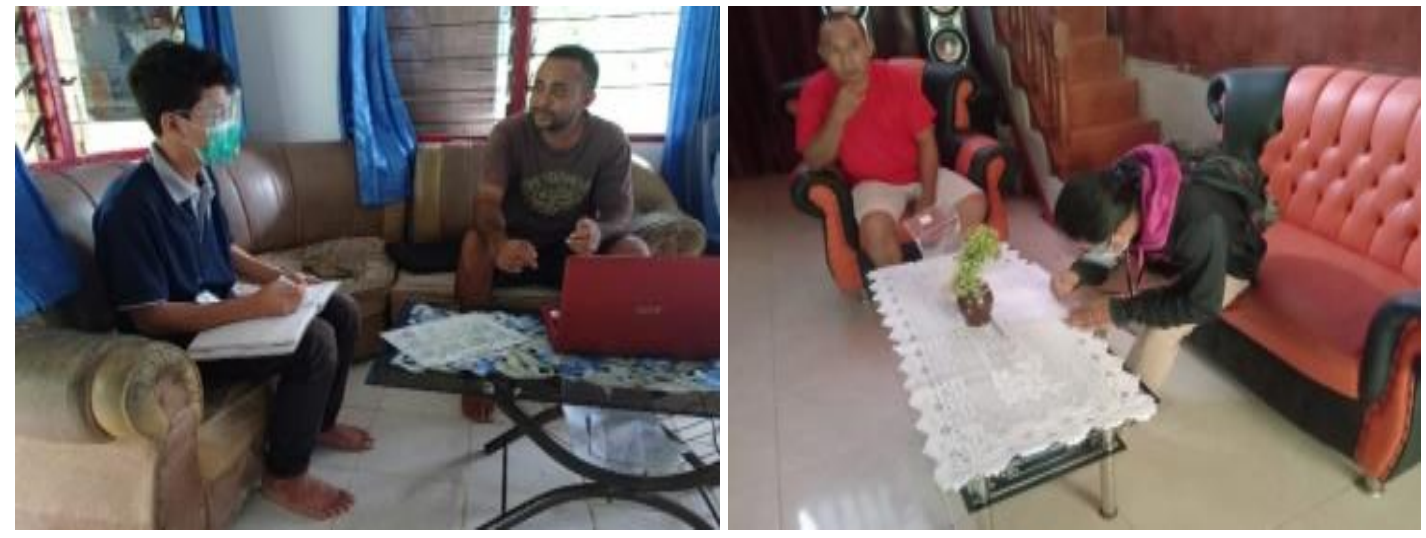

Gambar 3. Pendataan Jumlah Mitra yang Telah Mengikuti Vaksin

Pendataan ini dilakukan dengan dua katogori umur, yakni 12-17 tahun dan 18-60 tahun. Tujuan pembagian kategori ini untuk melengkapi data yang sudah dimiliki Gereja mengenai warga jemaat yang sudah vaksin dan belum melakukan vaksin. Penemuan tim dalam pendataan, ternyata ada mitra yang sudah melakukan vaksin dan juga belum vaksin. Sebagian besar yang belum vaksin mengaku siap untuk divaksin, ada yang mengaku memiliki penyakit bawaan di sertai 
surat keterangan dokter dan sebagian lagi menolak untuk divaksin karena selalu mendengar berita-berita hoax yang tersebar membuat mereka takut untuk divaksin. Di samping pendataan, tim juga melakukan advokasi terhadap mitra mengenai manfaat vaksin dan penerapan Protokol Kesehatan 5M sebagai bentuk spitualitas yang pro hidup. Harapan tim dari advokasi yang dilakukan, mitra dapat tergerak hati dan dengan kerelaan ingin untuk menerapkan Protokol Kesehatan 5M dengan tepat dan juga mau untuk divaksin.

\section{4) Kegiatan Pembagian Masker}

Kegiatan pembagian masker yang dilakukan tim kepada mitra dilaksanakan dengan cara membagi tugas oleh masingmasing anggota tim di keempat sektor yang ada di dalam Jemaat GPM Menara Kasih yakni sektor Eden, Sion, Getsemani dan Karmel. Pembagian Masker yang dilakukan oleh tim kepada mitra ini lebih dari satu hari disebabkan oleh faktor cuaca yang tidak bersahabat yakni hujan yang juga membuat jalanan menjadi licin, sehingga kegiatan ini dilakukan selama dua hari. Kegiatan ini dilakukan pada tanggal 6-7 Agustus 2021, dan tim memulai kegiatan ini mulai jam 09:00-18:00 WIT. Pembagian masker yang dilakukan oleh tim bertujuan agar setiap mitra dapat menaati protokol kesehatan $5 \mathrm{M}$ yang salah satunya juga adalah memakai masker.

Dalam kegiatan ini juga, selain tim membagikan masker kepada mitra, tim juga memberi himbauan kepada mitra untuk tetap menjaga dan menaati protokol kesehatan $5 \mathrm{M}$ yang telah dianjurkan agar dengan bersama dalam kehidupan bermasyarakat dan bergereja memperoleh kehidupan yang sama-sama dapat menjaga dan melindungi satu dengan yang lain.
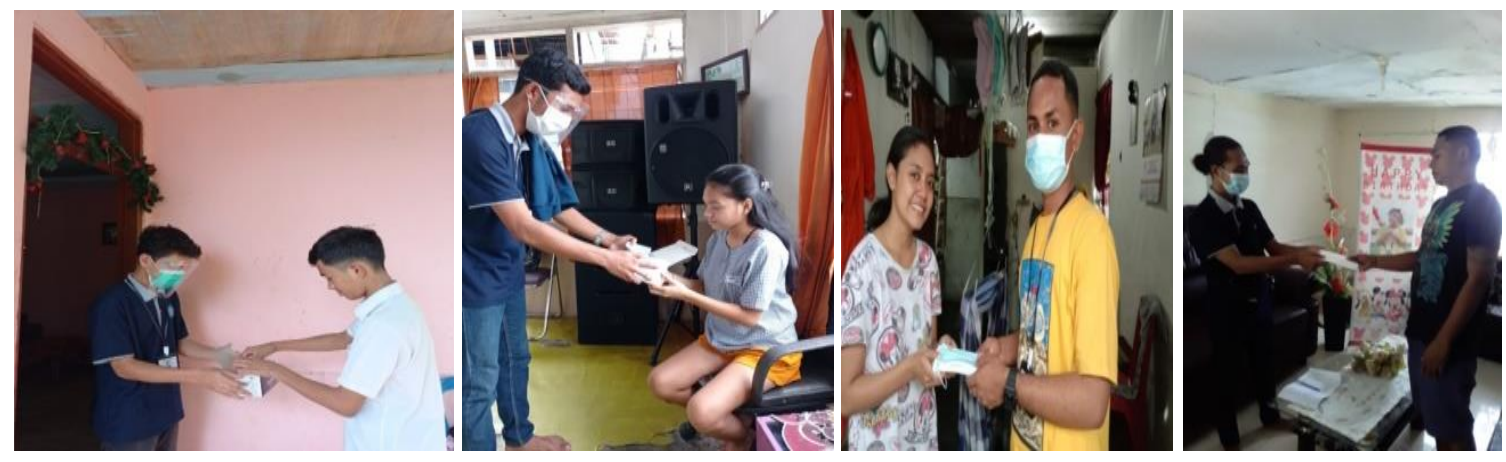

Gambar 4. Pembagian Masker Kepada Mitra

\section{5) Kegiatan Mengikuti Vaksin Oleh Mitra}

Pada tahapan kegiatan ini, mitra yang telah mengikuti webinar mengenai Vaksin dan pentingnya menerapkan protokol kesehatan 5M telah diajak untuk mengikuti vaksin di salah satu gedung gereja, yakni gedung Gereja GPM Menara Kasih. Berdasarkan data yang diperoleh dari proses pendataan tim, ternyata masih banyak sekali mitra yang belum ingin mengikuti vaksin, namun setelah mereka mengikuti webinar dan juga pendekatan advokasi dari tim untuk memberikan edukasi mengenai pentingnya vaksin, maka $85 \%$ mitra dengan kerelaan hati ingin mengikuti vaksin.

Tim bekerja sama dengan majelis jemaat GPM Menara Kasih untuk melibatkan mitra dalam proses vaksinasi yang dilakukan oleh Dinas Kesehatahn Kota Ambon, melalui Puskesmas Urimesing pada tanggal 12 Agustus 2021. Mitra yang mengikuti proses vaksinasi sekitar $85 \%$ dari jumlah keseluruhan mitra. Kegiatan vaksinasi yang berlangsung pukul 09.00-22.00 WIT itu berjalan dengan baik. Setelah mitra selesai mengikuti vaksin, mereka sangat bersyukur kepada tim karena telah membantu mereka memberikan edukasi tentang vaksin, sehingga mereka bisa terdorong untuk terlibat dalam proses vaksinasi. Mitra merasa selama ini kurang adanya informasi edukasi mengenai vaksin, sehingga mereka masih takut untuk mengikuti vaksin. Apa lagi mereka sering mendengar informasi-infomasi mengenai berita bohong (hoax) melalui berbagai media sosial dan juga orang lain tentang bahaya vaksin. 

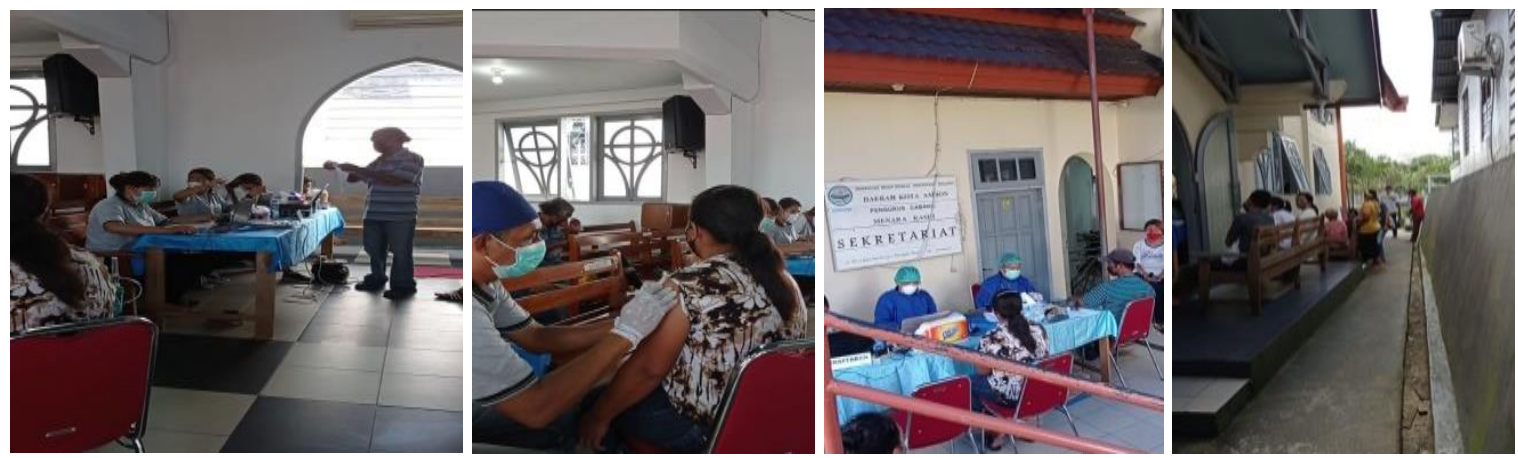

Gambar 5. Mitra Sedang Mengikuti Vaksin di Gedung GPM Menara Kasih

Luaran yang dihasilkan dari kegiatan-kegiatan ini terbilang sangat memuaskan, dikarenakan sosialisasi dan advokasi yang dilakukan tim kepada mitra dianggap sangat bermanfaat dan membantu mereka, karena di situlah mereka dapat teredukasi dan terdorong untuk mengikuti seluruh kegiatan. Hasil kegiatan yang sangat memuaskan itu dapat terlihat dari indikator capaian yang diperoleh, di mana mitra yang telah mengikuti vaksin sekitar 85 persen. Didapati, rata-rata mitra belum pernah tahu dan mengenal lebih dalam tentang apa dan manfaat vaksin serta pentingnya menerapkan protokol kesehatan 5M di tengah Pandemi-19. Dengan demikian, mitra merasa ini tindakan penting yang dilakukan tim, sehingga mereka akan terus menerapkan protokol kesehatan 5M dan mengikuti vaksin tahap kedua juga.

\section{Kesimpulan}

Dari berbagai permasalahan yang dialami oleh Mitra ini, langkah yang dilakukan adalah untuk mengedukasi umat dalam menerapakan pola hidup sehat yang bebas dari COVID-19. Pola hidup sehat adalah bagian dari tanggung jawab Iman. Menjaga kesehatan dan Iman adalah bentuk spiritualitas melindungi diri. Orang Kristen percaya kepada Allah yang merawat kehidupan adalah orang Kristen yang tidak hanya berdoa saja tetapi berdoa dilengkapi dengan perbuatan nyata. Menjalankan protocol kesehatan 5M (Memakai masker, Mencuci tangan, Menjaga jarak, Menghindari kerumunan, dan Mengurangi mobilitas) merupakan tindakan spitualitas yang menjaga hidup. Selain protocol kesehatan, vaksin adalah salah satu jalan untuk menambah kekuatan imun tubuh agar terhindar dari penyebaran coronavirus, dan ini juga merupakan bagian dari tanggungjawab iman sebagai pemuda dan remaja dalam merefleksikan suara Tuhan dan karya keselamatan-Nya melalui vaksin. Dalam lingkungan mitra dapat dikatan telah menyebar virus ini dan karena itu, penyemprotan desinvektan juga salah satu cara untuk menstetrilkan lingkungan mitra, juga termasuk salah satu bentuk menghindari mitra dari penyebaran coronavirus.

\section{References}

Adiprasetya, J. (2006). Labirin Kehidupan, Spiritualitas sehari-hari Bagi Peziarah Iman, Jakarta: BPK Gunung Mulia Anamofa, J.N. (2013). Studying Christian Spirituality. Jurnal UNIERA, 2(2).

Azmi, N. (2021). Pengaruh Pandemi Terhadap Kesehatan Remaja, dilansir dari https: //hellosehat.com,infeksi/COVID19/dampak-pandemi-mental-remaja, Access: 17 August 2021.

Dariyo, A. (2003). Psikologi Perkembangan Dewasa Muda, Jakarta: GRASINDO

Darmaputera, E. (2010). "Spiritualitas Baru dan Kepedulian terhadap Sesama" in Stefanus Christian Haryono. “Spiritualitas” Jakarta: BPK Gunung Mulia

Foster, R. (2005). Tertib Rohani, Sudahkan Anda Menapakinya? Malang: Gandum Mas

Haryono, S.C. (2010), "Spiritualitas" dalam Meniti Kalam Kerukunan, edt, Nur Kholis, setiawan \& Djaka Soetapa, 2020, Jakarta: BPK Gunung Mulia 
Hughes, R.K. (2001). Disciplines of a Godly Man, Wheaton: Crossway

Hurlock, E.B. (2013). Psikologi Perkembangan: Suatu Pendekatan Sepanjang Rentang Kehidupan, Jakarta: Penerbit Erlangga

Kabupaten Buleleng. (2021). Pemuda Potensi Masalah Peran dan Harapan untuk Bangsa. https://kesrasetda.bulelengkab.go.id/informasi/detail/artikel/pemuda-potensi-masalah-peran-dan-harapanuntuk-bangsa-25

Kementerian Kesehatan RI. (2020). Buku Saku: Info Vaksin, Jakarta

Latifah, N.R.D. (2020). Kebijakan Terkait Pandemi COVID-19, Yogyakarta: MBridge Press

Lewier, F. C. (2003), Manajemen PAK bagi Pemuda/Mahasiswa Menyongsong dan Memasuki Abad Ke-21, dalam Ajarlah Mereka Melakukan, ed. Andar Ismail, Jakarta: BPK Gunung Mulia

Majelis Jemaat. (2021). Rencana Strategi Jemaat GPM Menara Kasih 2021-2025, Ambon.

Masela, P. (2020). Dampak Pandemi COVID-19 terhadap Implementasi Pembelajaran Daring, Stie Insan Pembangunan

McGrath, A.E. (2007). Spiritualitas Kristen, Medan: Penerbit Bina Medya Perintis

Mutak, A.A. (2016). Dispilin Rohani Sebagai praktek Ibadah. Jurnal Theologi Aletheia, 18(10).

Nurmalita, S. (2016). Siapa Itu Remaja, Purwokerto

Pemerintah Kota Ambon. (2021). COVID-19. https://ambon.go.id/COVID-19/, Access: 17 August 2021.

Perrin, D.B. (2007). Studying Christian Spirituality, Routledge-New Your and London

Pratama, M.A. (2020). Dampak COVID-19, Jakarta

Touwely, G. H., Nanuru, R. F., Laisila, M., \& Dandirwalu, R. (2019). Assistance on Writing Scientific Papers for Students of Nusaniwe Village. Indones. J. Cult. Community Dev., 4(1), 23-31, DOI: 10.21070/ijccd.v2i3.70.

Wakhudin, et.al. (2020). COVID-19 Dalam Ragam Tinjauan Perspektif, Yogyakarta: MBridge Press

Wilhoit, J.C. (2008). Spiritual Formation as if the Church Mattered: Growing in Christ through Community. Grand Rapids: Baker Academic 